\title{
Activation of $\mathrm{SO}_{2}$ by $\mathrm{N} / \mathrm{Si}^{+}$and $\mathrm{N} / \mathrm{B}$ Frustrated Lewis Pairs: Experimental and Theoretical Comparison with $\mathrm{CO}_{2}$ Activation
}

\author{
Aurélien Adenot, ${ }^{[a]}$ Niklas von Wolff, ${ }^{[a]}$ Guillaume Lefèvre, ${ }^{[a]}$ Jean-Claude Berthet, ${ }^{\left[{ }^{[a]}\right.}$ Pierre Thuéry, ${ }^{[a]}$ and \\ Thibault Cantat*[a]
}

\begin{abstract}
The guanidine 1,5,7-triazabicyclo[4.4.0]dec-5-ene (TBD) and the substituted derivatives $\left[\mathrm{TBD}-\mathrm{SiR}_{2}\right]^{+}$and $\mathrm{TBD}-\mathrm{BR}_{2}$ reacted with $\mathrm{SO}_{2}$ to give different $\mathrm{FLP}-\mathrm{SO}_{2}$ adducts. Molecular structures, elucidated by $\mathrm{X}$-ray diffraction, showed some structural similarities with the analogous $\mathrm{CO}_{2}$ adducts. Thermodynamic stabilities were both experimentally evidenced and computed through DFT calculations. The underlying parameters governing the relative stabilities of the different $\mathrm{SO}_{2}$ and $\mathrm{CO}_{2}$ adducts were then discussed from a theoretical standpoint, with a focus on the influence of the Lewis acidic moiety.
\end{abstract}

\section{Introduction}

In the last few years, the development of Frustrated Lewis Pairs (FLPs) has shown a significant progress ${ }^{[1]}$ thanks to the impulse given by Stephan and Erker who have demonstrated the ability of FLPs to reversibly activate and release dihydrogen. ${ }^{[2]} \mathrm{H}_{2}$ splitting and its application in the reduction of various organic substrates is still one of the most prominent features of FLPs. ${ }^{[1]}$ These latter are also known to bind to various functional groups (such as alkenes ${ }^{[3]}$, alkynes ${ }^{[4]}$, azides ${ }^{[5]}$, carbonyl compounds ${ }^{[6]}$, etc.) and activate a variety of small molecules. ${ }^{[1]} \mathrm{A}$ special focus has notably been given to carbon dioxide, ${ }^{[7,18,19]}$ as a result of its attractiveness as a cheap, nontoxic and abundant $C_{1}$-building block. ${ }^{[8]}$ Beyond capture, FLP-mediated $\mathrm{CO}_{2}$ reductions have also been explored..$^{[9,18,19]}$

Sulfur dioxide, $\mathrm{SO}_{2}$, is both a toxic and environmentally problematic gas $^{[10]}$ as well as a S-containing feedstock for chemicals. ${ }^{[11]}$ The activation of $\mathrm{SO}_{2}$ with FLPs has been scarcely studied and only a few examples of isolated adducts have been reported. ${ }^{[12-15]}$ Examples mostly include systems containing a boron center as the acidic site and a phosphorus center as the basic site $(B / P),{ }^{[12]}$ even though $B / C,{ }^{[13]} \mathrm{M} / \mathrm{P}$ (with $\mathrm{M}=\mathrm{Zr}$ or Hf) ${ }^{[14]}$ and $\mathrm{Si} / \mathrm{P}^{[15]}$ combinations were also reported (Chart 1$)$. While a wealth of knowledge exists regarding complexes of $\mathrm{SO}_{2}$ with amines, ${ }^{[16]}$ no FLP involving an amine as a Lewis base has been reported to form an adduct with $\mathrm{SO}_{2}$.

Our group recently demonstrated that guanidine $1,5,7-$ triazabicyclo[4.4.0]dec-5-ene (TBD) ${ }^{[17]}$ and the relative derivatives featuring a boryl or silylium site, TBD-BR ${ }^{[18]}$ and $\left[\mathrm{TBD}-\mathrm{SiR}_{2}\right]^{+},{ }^{[19]}$ strongly bind to $\mathrm{CO}_{2}$ and other heterocumulenes ${ }^{[20]}$ to yield stable adducts (Schemes 2 and 3). While $\mathrm{SO}_{2}$ and $\mathrm{CO}_{2}$ molecules have distinct chemical properties, they are readily trapped by FLPs to form similar adducts. ${ }^{[12,14,15]}$ The structural characteristics and

[a] NIMBE, CEA, CNRS, Université Paris-Saclay, CEA Saclay 91191 Gif-sur-Yvette, France

E-mail: thibault.cantat@cea.fr

http://iramis.cea.fr/Pisp/thibault.cantat/index.html

Supporting information for this article is given via a link at the end of the document. chemical behaviors of the FLP- $\mathrm{ZO}_{2}(\mathrm{Z}=\mathrm{C}, \mathrm{S})$ adducts have however never been compared and discussed. Herein, we report the synthesis, structural characterization, and reactivity of a series of guanidine- $\mathrm{SO}_{2}$ adducts in which different Lewis acids are incorporated. The trends in their structures and relative stabilities (with respect to the $\mathrm{CO}_{2}$ analogues) have been established from experimental and theoretical (DFT) data.

Chart 1. Exhaustive collection of adducts obtained from the activation of $\mathrm{SO}_{2}$ by FLPs. ${ }^{[4-7]}$

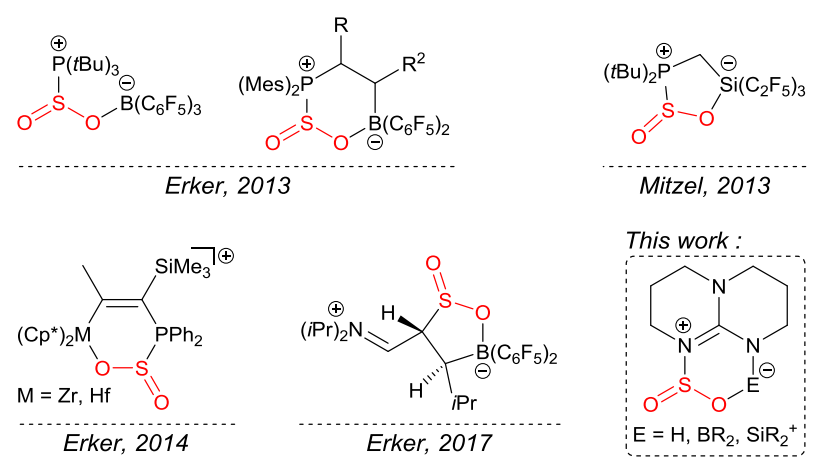

\section{Results and Discussion}

\section{Synthesis and Crystal Structures of the Compounds}

As previously reported by our group, exposition of a THF solution of TBD to $1 \mathrm{~atm}$ of $\mathrm{CO}_{2}$ affords the zwitterionic adduct $\mathbf{1}$, which crystallizes under polymorphic variants. ${ }^{[17,20]}$ Several heterocumulenes $(X=C=Y$ with $X, Y=N R, O, S)$, which have a similar structure and reactivity as $\mathrm{CO}_{2}$, have also proven to form adducts with TBD. ${ }^{[20]}$ Following these studies and reasoning that $\mathrm{SO}_{2}$ is a stronger Lewis acid than $\mathrm{CO}_{2}$, the reaction of TBD with sulfur dioxide was investigated. Treatment at room temperature of a THF solution of TBD with 2 equiv. of $\mathrm{SO}_{2}$ (generated by thermal decomposition of $\mathrm{K}_{2} \mathrm{~S}_{2} \mathrm{O}_{5}$ ) provided the adduct 2 quantitatively.

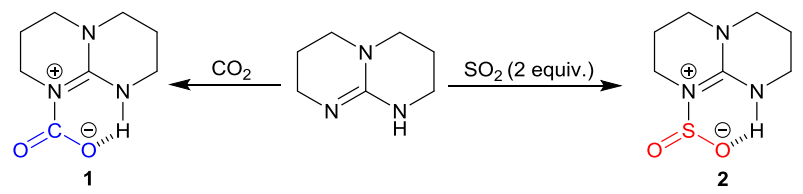

Scheme 1. Synthesis of TBD- $\mathrm{ZO}_{2}$ adducts (with $\mathrm{Z}=\mathrm{C}$ or $\mathrm{S}$ ). $\mathrm{SO}_{2}$ gas generated by thermal decomposition of $\mathrm{K}_{2} \mathrm{~S}_{2} \mathrm{O}_{5}$.

The replacement of the acidic hydrogen atom in TBD by a boryl fragment $\left(\mathrm{BR}_{2}\right)^{[18]}$ or a silylium group $\left(\mathrm{SiR}_{2}{ }^{+} \mathrm{Cl}^{-}\right)^{[19]}$ affords 
$[\mathrm{TBD}-\mathrm{E}]^{\mathrm{q+}}\left(\mathrm{E}=\mathrm{SiR}_{2}, \mathrm{q}=1 ; \mathrm{BR}_{2}, \mathrm{q}=0\right)$ derivatives containing both a basic guanidine and a Lewis acidic site. These compounds are prone to act as an intramolecular FLP to trap $\mathrm{CO}_{2}$ and form corresponding $\mathrm{FLP}-\mathrm{CO}_{2}$ adducts $4[\mathrm{Cl}], 7_{\mathrm{BBN}}$ and $7_{\mathrm{BCy} 2}$ (Schemes 2 and 3). Importantly, these species have shown to be highly active hydroboration catalysts for the conversion of $\mathrm{CO}_{2}$ to methanol derivatives ${ }^{[18,19]}$ and the more oxophilic silyl cation exhibits increased performances. ${ }^{[19]}$ The successful formation and isolation of the $\mathrm{SO}_{2}$-adduct 2 prompted us to investigate the reaction of [TBD-E] FLPs with sulfur dioxide, to modulate the activation of $\mathrm{SO}_{2}$ by introducing different Lewis acidic sites: $\mathrm{E}=\mathrm{BR}_{2}$ and $\mathrm{SiR}_{2}{ }^{+} \mathrm{Cl}^{-}$.

Exposing a THF solution of TBD-SiMe ${ }_{2} \mathrm{Cl}(3[\mathrm{Cl}])$ to 2 equiv. of $\mathrm{SO}_{2}$ did not change the color of the solution but formation of a new single species $5[\mathrm{Cl}]$ was evidenced from the ${ }^{1} \mathrm{H}$ and ${ }^{13} \mathrm{C}$ NMR spectra of the crude mixture. This compound could not be isolated as the fixation of $\mathrm{SO}_{2}$ was reversible and $\mathrm{SO}_{2}$ was rapidly released during evaporation of the solvent or when the solution was purged with argon. The quantitative fixation of $\mathrm{SO}_{2}$ in $3[\mathrm{Cl}]$ under a low pressure of gas, can be compared to the corresponding $\mathrm{CO}_{2}$ insertion which gave $4[\mathrm{Cl}]$ with only $30 \%$ conversion (by NMR) under 1 bar of $\mathrm{CO}_{2}$ in THF. ${ }^{[19]}$ In the latter case, the trapping of $\mathrm{CO}_{2}$ was strongly dependent on the nature of the solvent $\left(80 \%\right.$ of $4[\mathrm{Cl}]$ in $\left.\mathrm{CH}_{2} \mathrm{Cl}_{2}\right)$ and the regeneration of the precursor $3[\mathrm{Cl}]$ required much longer times $(24 \mathrm{~h})$ than from the FLP-SO ${ }_{2}$ adduct $5[\mathrm{Cl}]$ ( $<1 \mathrm{~min}$ ). The influence of the counter-anion in the reversibility of these reactions was also demonstrated by the difficulty of the stable adduct $4\left[\mathrm{~B}\left(\mathrm{C}_{6} \mathrm{~F}_{5}\right)_{4}\right]$ to release $\mathrm{CO}_{2}$ in comparison to $4[\mathrm{Cl}]$. It is likely that the nucleophilic attack of the chloride anion on the silicon atom of $4[\mathrm{Cl}]$ favored regeneration of $3[\mathrm{Cl}$. Complex $5[\mathrm{Cl}]$ did not crystallized in THF but colorless crystals of $5\left[\mathrm{BPh}_{4}\right]$-benzene, suitable for a X-ray diffraction study, were obtained by slow diffusion of pentane into a benzene solution of $5[\mathrm{Cl}]$ containing an excess $\mathrm{NaBPh}_{4}$.

$$
\text { (1) } \mathrm{Ke}_{2} \mathrm{SiCl}_{2}
$$

Scheme 2. Synthesis of TBD-SiMe $-Z_{2} \mathrm{O}_{2}$ adducts (with $\mathrm{Z}=\mathrm{C}$ or $\mathrm{S}) . \mathrm{SO}_{2}$ gas generated by thermal decomposition of $\mathrm{K}_{2} \mathrm{~S}_{2} \mathrm{O}_{5}$.

By contrast, the neutral boron dimer $[\mathrm{TBD}-\mathrm{BBN}]_{2}\left(6_{\mathrm{BBN}}\right)$, insoluble in THF, remained inert in the presence of $\mathrm{SO}_{2}$, even after 7 days at $120{ }^{\circ} \mathrm{C}$, while it activated $\mathrm{CO}_{2}$ within 85 min at $100^{\circ} \mathrm{C} \cdot{ }^{[18]}$ The absence of reactivity of $6_{\mathrm{BBN}}$ with $\mathrm{SO}_{2}$, monitored in a variety of solvents $\left(\mathrm{Et}_{2} \mathrm{O}\right.$, pentane, benzene, acetonitrile, $\mathrm{CH}_{2} \mathrm{Cl}_{2}$, and pyridine), can be related to its insolubility. This difference in reactivity between the two small molecules is surprising and may not be attributed to their difference of solubility in organic solvents. ${ }^{[21]}$ In contrast, the THF soluble dimer [TBD$\left.\mathrm{BCy}_{2}\right]_{2}\left(6_{\mathrm{BCy}}\right)$ instantaneously formed the $\mathrm{CO}_{2}$-adduct $7_{\mathrm{BCy} 2}$ and the corresponding $\mathrm{SO}_{2}$-adduct $8_{\mathrm{BCy}}$ when exposed to $1 \mathrm{~atm}$ of $\mathrm{CO}_{2}$ or 2 equiv. of $\mathrm{SO}_{2}$, at $25^{\circ} \mathrm{C}$. Colorless crystalline platelets of $\mathbf{7}_{\mathrm{BCy} 2}$ and $\mathbf{8}_{\mathrm{BCy} 2} \cdot(\mathrm{THF})_{0.5}$ were obtained by slow diffusion of pentane into a concentrated THF solution of the compound

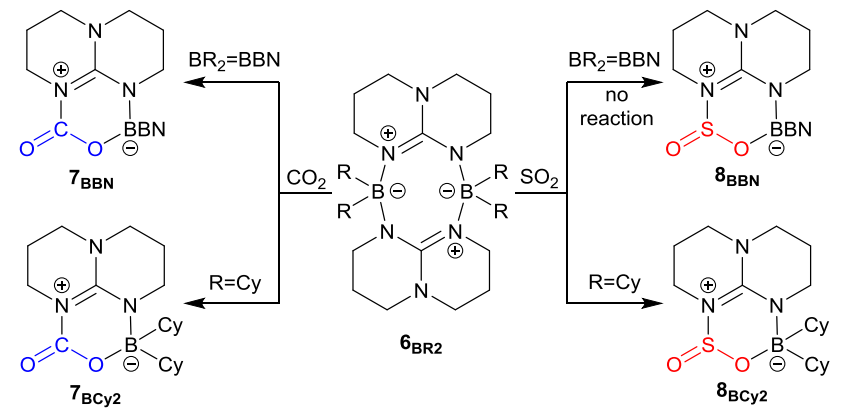

$\mathrm{BBN}=$ borabicyclo[3.3.1]nonane

Scheme 3. First route to access the TBD- $B R_{2}-Z_{2}$ adducts (with $Z=C$ or $S$ and $\mathrm{BR}_{2}=\mathrm{BCy}_{2}$ or $\mathrm{BBN}$ ). $\mathrm{SO}_{2}$ gas generated by thermal decomposition of $\mathrm{K}_{2} \mathrm{~S}_{2} \mathrm{O}_{5}$.

Because the insolubility of $[\mathrm{TBD}-\mathrm{BBN}]_{2}\left(\mathbf{6}_{\mathrm{BBN}}\right)$ proved to be detrimental, alternative routes to adducts $8_{\mathrm{BR} 2}$ were devised, to tackle the problematic formation of dimer $\mathbf{6}_{\mathrm{BR} 2}$ (Scheme 4). In a first route (path a), addition of a dialkylborane halide on the preformed TBD- $\mathrm{SO}_{2}$ adduct 2 afforded a new species attributed by NMR to the coordination of the boron center to one oxygen atom of the $\mathrm{SO}_{2}$ fragment. The expected FLP adduct $\mathbf{8}_{\mathrm{BR} 2}$ was then obtained by deprotonation of the guanidine backbone with a strong base (1,8-diazabicyclo[5.4.0]undec-7-ene (DBU)). Nonetheless, isolation of adducts $\mathbf{8}_{\mathbf{B R} 2}$ from the crude reaction proved unsatisfactory, due to contamination with the $[\mathrm{DBUH}][\mathrm{X}]$ byproduct. The use of other strong bases (e.g. HMDS, KH, Proton-sponge, $\mathrm{LiNMe}_{2}, 1,1,3,3$-Tetramethylguanidine) was not conclusive. Only $8_{\mathrm{BC} 2}$ could be clearly characterized by its crystal structure from this synthetic pathway. Another method (path b) based on the successive treatment of the guanidinate anion [TBD-] with $\mathrm{SO}_{2}$ then $\mathrm{R}_{2} \mathrm{~B}-\mathrm{X}$ was investigated to form $\mathbf{8}_{\mathrm{BR} 2}$ via a sulfinate species. Neutral compounds $\mathbf{8}_{\mathrm{BBN}}$ and $\mathbf{8}_{\mathrm{BC} 2}$ were successfully obtained and did not show propensity to release $\mathrm{SO}_{2}$ under vacuum.

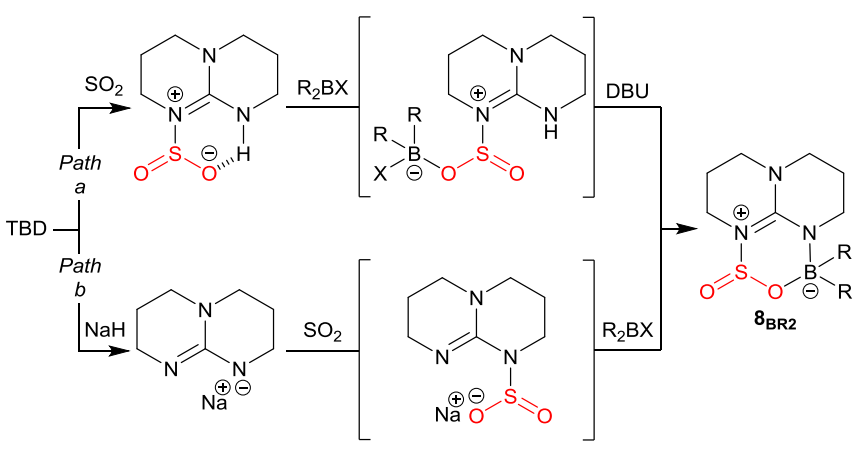

Scheme 4. Other routes towards TBD- $\mathrm{BR}_{2}-\mathrm{ZO}_{2}$ adducts (with $\mathrm{Z}=\mathrm{C}$ or $\mathrm{S}$ and $\mathrm{BR}_{2}=\mathrm{BC} \mathrm{y}_{2}$ or $\mathrm{BBN}$ ). $\mathrm{SO}_{2}$ gas generated by thermal decomposition of $\mathrm{K}_{2} \mathrm{~S}_{2} \mathrm{O}_{5}$. 
Views of the X-ray structures of TBD-SO 2 and the FLP$\mathrm{SO}_{2}$ adducts $5\left[\mathrm{BPh}_{4}\right]$ and $\mathbf{8}_{\mathrm{BCy}}$ are presented in Figure 1. Selected bonds lengths and angles are provided in Table 1. The structure of $\mathbf{2}$ is quite similar to that of its $\mathrm{CO}_{2}$ counterpart $\mathbf{1}^{[17,20]}$ with the nitrogen atom N1 of TBD bonded to the sulfur atom of $\mathrm{SO}_{2}$ and the sulfinate moiety stabilized through an $\mathrm{O} \cdots \mathrm{H}$ intramolecular hydrogen bond, involving the proton on the proximal N2 atom. However, in contrast to 1, the acidic proton on N2 is involved in a bifurcated hydrogen bond resulting in an intermolecular interaction with the $\mathrm{O} 1$ atom of another sulfinate moiety, thus forming a centrosymmetric dimer.

[a]

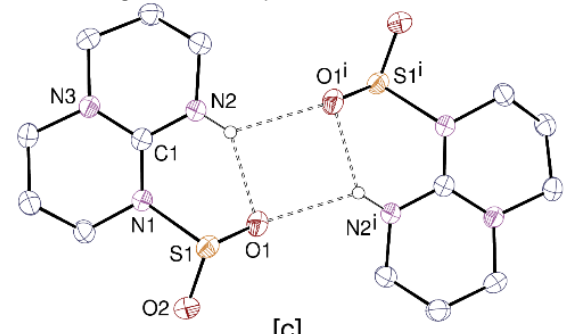

[b]

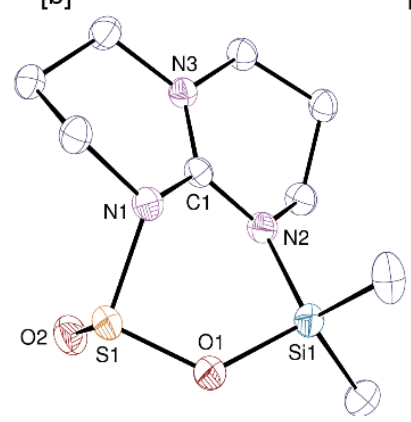

[c]

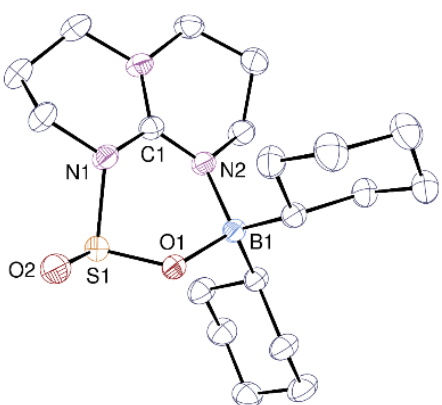

Figure 1. Molecular structures of [a] TBD-SO $\mathrm{SO}_{2}$ 2, [b] TBD- $\mathrm{SiMe}_{2}-\mathrm{SO}_{2}$ $5[\mathrm{BPh} 4]$ and $[\mathrm{C}] \mathrm{TBD}-\mathrm{BC} \mathrm{y}_{2}-\mathrm{SO}_{2} \mathbf{8}_{\mathrm{BCy}}$. Carbon-bound hydrogen atoms and solvent molecules are omitted. Hydrogen bonds are shown as dashed lines. Symmetry code: $\mathrm{i}=-x, 1-y, 1-z$.

The zwitterionic nature of $\mathbf{2}$ is clearly evidenced by the planarity of the C1N1N2N3 unit (root mean square (rms) deviation of $0.004 \AA$, with a mean $\mathrm{C}-\mathrm{N}$ distance of $1.344(6) \AA$ ) which is characteristic of a delocalized guanidinium-type cationic system. The negative charge is delocalized on a sulfinate-type anionic S1O1O2 moiety, displaying two close S-O distances [S1-O1

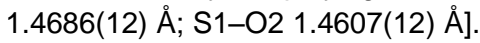

The $\mathrm{S}-\mathrm{O}$ distances are elongated with respect to free gaseous $\mathrm{SO}_{2}(1.4299 \text { (3) } \AA)^{[22 a]}$ and can be compared to those in neutral amine- $\mathrm{SO}_{2}$ complexes (1.467(1) $\AA$ for $\mathrm{Me}_{2} \mathrm{HN}-\mathrm{SO}_{2},{ }^{[22 \mathrm{~b}]}$ $1.436(4) \AA$ for $\mathrm{Me}_{3} \mathrm{~N}-\mathrm{SO}_{2}{ }^{[22 \mathrm{c}]}$ or $1.452(3) \AA$ for $\left.\mathrm{DABCO} \cdot\left(\mathrm{SO}_{2}\right)_{2}{ }^{[16 \mathrm{~g}]}\right)$. These $\mathrm{S}-\mathrm{O}$ distances are slightly shorter than those in $\mathrm{ArSO}_{2} \mathrm{Na}$ species for which the mean bond length is ca $1.52 \AA_{.}{ }^{[23]}$ The N1-S1 bond length in $2(1.8730(13) \AA)$ is smaller than those reported in the zwitterions $\mathrm{Me}_{2} \mathrm{HN}-\mathrm{SO}_{2}$ $(2.006(2) \AA),{ }^{[22 b]} \mathrm{Me}_{3} \mathrm{~N}-\mathrm{SO}_{2}(2.046 \AA)^{[22 \mathrm{c}]}$ or in DABCO $\cdot\left(\mathrm{SO}_{2}\right)_{2}$ $(2.0958(14)$ and $2.1732(15) \AA) .{ }^{[16 g]}$ These distances reflect the basicity of the amine, with shorter distances measured with stronger bases. TBD displays indeed a greater Brønsted basicity $\left(\mathrm{p} K_{\mathrm{a}}=26\right)$ than tertiary amines $\left(\mathrm{p} K_{\mathrm{a}} \sim 17-20\right)$ and DABCO (8.8). The contracted $\mathrm{N} 1-\mathrm{S} 1$ distances in 2 vs $\mathrm{DABCO} \cdot\left(\mathrm{SO}_{2}\right)_{2}$ would suggest an enhanced stability of the adduct and a lower propensity to loose $\mathrm{SO}_{2}$.

The O2-S1-O1 angle of $112.30(7)^{\circ}$ is close to those in $\mathrm{Me}_{2} \mathrm{H}-\mathrm{N}-\mathrm{SO}_{2}\left(112.8(1)^{\circ}\right)^{[22 \mathrm{~b}]}$ and $\mathrm{Me}_{3} \mathrm{~N}-\mathrm{SO}_{2}\left(113.7(3)^{\circ}\right),{ }^{[22 c]}$ and slightly larger than those reported in sulfinate $\mathrm{ArSO}_{2} \mathrm{Na}$ compounds $\left(\mathrm{ca} 108^{\circ}\right) .{ }^{[23]}$ The tetrahedral geometry of the sulfur atom explains the strong distortions in the NCNEOZ $(E=B$ or $\mathrm{Si}$, $\mathrm{Z}=\mathrm{C}$ or $\mathrm{S}$ ) cycles of $5\left[\mathrm{BPh}_{4}\right]$ and $\mathbf{8}_{\mathrm{BCy} 2}$ in comparison to the $\mathrm{CO}_{2}$ analogues $4[\mathrm{Cl}]$ and $7 \mathrm{BCy}$.

The major features in the three boryl- and silylium-based $\mathrm{FLP}-\mathrm{CO}_{2}$ compounds versus TBD- $\mathrm{CO}_{2}$ revealed acute $\mathrm{O}-\mathrm{C}-\mathrm{O}$ angles $\left(121-126^{\circ}\right.$ vs $128.59(19)^{\circ}$ for 1$)$ and dissymmetric $\mathrm{C}-\mathrm{O}$ bonds. The differences in $\mathrm{C}-\mathrm{O}$ distances reach $0.08 \AA$ (in $7_{\mathrm{BCy} 2}$ and $7_{\mathrm{BBN}}$ ) and $0.116 \AA$ (in $4[\mathrm{Cl}]$ ) while the gap is less pronounced in $1(0.03 \AA)$. Similarly, the O-S-O angles in $5[\mathrm{Cl}]$ and $\mathbf{8}_{\mathrm{BCy} 2}$ are similar $\left(\mathrm{ca} 107^{\circ}\right)$ and smaller than in $2\left(112.30(7)^{\circ}\right)$ and the S-O bond lengths are dissymmetric in both $8_{\mathrm{BCy}}$ and $5\left[\mathrm{BPh}_{4}\right]$ (differences reach 0.08 and $0.15 \AA$, respectively). The higher asymmetry in the $\mathrm{ZO}_{2}$ fragment of $4[\mathrm{Cl}]$ and $5\left[\mathrm{BPh}_{4}\right]$ suggests a greater activation by the $\mathrm{SiMe}_{2}$ fragment as a result of a stronger Lewis acidity.

To compare the relative stabilities of the newly synthesized FLP-SO $\mathrm{SO}_{2}$ adducts toward their $\mathrm{CO}_{2}$ analogues, the latter compounds were treated with $\mathrm{SO}_{2}$ to monitor competition reactions. When treated with 2 equivalents of sulfur dioxide, TBD$\mathrm{CO}_{2}$ adduct 1 was totally converted into compound $\mathbf{2}$, which was inert under a $\mathrm{CO}_{2}$ atmosphere. In contrast, all three compounds $7_{\mathrm{BBN}}, 7_{\mathrm{BCy} 2}$ and $4\left[\mathrm{~B}\left(\mathrm{C}_{6} \mathrm{~F}_{5}\right)_{4}\right]$ remained inert toward sulfur dioxide exposure (and the same applies for the reverse transformations, see Scheme 5).
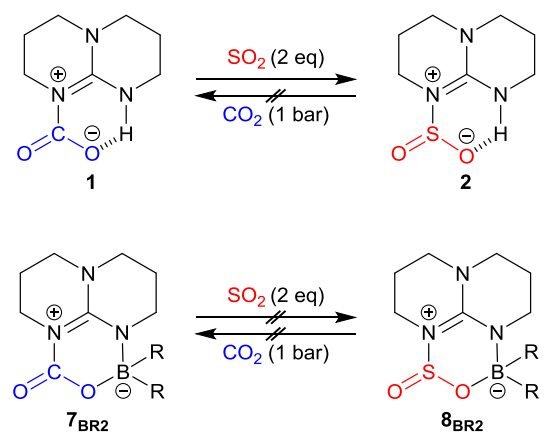

Scheme 5.
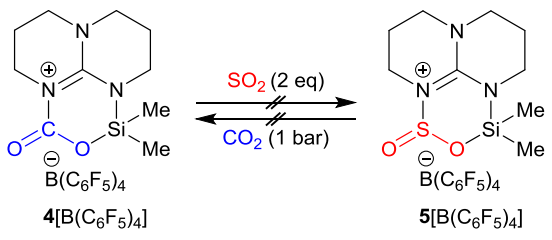

Competition reactions of $\mathrm{ZO}_{2}$ adducts (with $\mathrm{Z}=\mathrm{C}$ or $\mathrm{S}$ ).

This outcome evidences a greater stability of the TBD- $\mathrm{SO}_{2}$ adduct 2 compared to its $\mathrm{CO}_{2}$ analogue 1 . The absence of any small molecule displacement in the case of functionalized guanidines $7_{\mathrm{BR} 2}$ and $4\left[\mathrm{~B}\left(\mathrm{C}_{6} \mathrm{~F}_{5}\right)_{4}\right]$ may reveal a high kinetic barrier for the extrusion of $\mathrm{ZO}_{2}(\mathrm{Z}=\mathrm{C}$ or $\mathrm{S})$. We were therefore interested in rationalizing the observed trends in reactivity and in 
Table 1. Selected bond lengths $(\AA)$ and angles $\left({ }^{\circ}\right)$ in TBD-E- $\mathrm{ZO}_{2}$ adducts (with $E=H, \mathrm{SiMe}_{2}{ }^{+}, \mathrm{BCy}_{2}$ or $\mathrm{BBN}$ and $\mathrm{Z}=\mathrm{C}$ or $\mathrm{S}$ ).

\begin{tabular}{|c|c|c|c|c|c|c|c|c|}
\hline Compound & $N^{1} Z$ & $\mathrm{ZO}^{1}$ & $\mathrm{ZO}^{2}$ & $\mathrm{O}^{1} \mathrm{E}$ & $\mathrm{EN}^{2}$ & $\mathrm{~N}^{2} \mathrm{C}^{1}$ & $\mathrm{~N}^{1} \mathrm{C}^{1}$ & $\mathrm{O}^{1} \mathrm{ZO}^{2}$ \\
\hline $\mathrm{TBD}-\mathrm{CO}_{2}(\mathbf{1})^{[17]}$ & $1.480(3)$ & $1.229(2)$ & $1.257(3)$ & - & - & $1.332(2)$ & $1.369(3)$ & $128.59(19)$ \\
\hline $\mathrm{TBD}-\mathrm{SO}_{2}(\mathbf{2})^{[\mathrm{a}]}$ & $1.8730(13)$ & $1.4686(12)$ & $1.4607(12)$ & - & - & $1.3461(19)$ & $1.3488(19)$ & $112.30(7)$ \\
\hline$\left[\mathrm{TBD}-\mathrm{SiMe}_{2}-\mathrm{CO}_{2}\right][\mathrm{Cl}](4[\mathrm{Cl}])^{[19]}$ & $1.395(4)$ & $1.322(4)$ & $1.206(4)$ & $1.671(2)$ & $1.756(2)$ & $1.331(4)$ & $1.392(4)$ & $121.4(3)$ \\
\hline$\left[\mathrm{TBD}-\mathrm{SiMe}_{2}-\mathrm{SO}_{2}\right]\left[\mathrm{BPh}_{4}\right]\left(\mathbf{5}\left[\mathrm{BPh}_{4}\right]\right)^{[\mathrm{a}]}$ & $1.7054(17)$ & $1.5888(15)$ & $1.4394(17)$ & $1.6871(15)$ & $1.7591(17)$ & $1.349(3)$ & $1.371(2)$ & $107.06(9)$ \\
\hline TBD-BBN-CO $2\left(7_{\mathrm{BBN}}\right)^{[18]}$ & $1.410(3)$ & $1.299(3)$ & $1.222(2)$ & $1.537(3)$ & $1.585(3)$ & $1.319(3)$ & $1.388(3)$ & $123.9(2)$ \\
\hline $\mathrm{TBD}-\mathrm{BCy}_{2}-\mathrm{CO}_{2}\left(7_{\mathrm{BCy} 2}\right)^{[\mathrm{a}]}$ & $1.4158(14)$ & $1.2949(13)$ & $1.2186(13)$ & $1.5356(13)$ & $1.5918(14)$ & $1.3153(14)$ & $1.3894(13)$ & $124.09(10)$ \\
\hline
\end{tabular}

[a] This work.

understanding the underlying principles governing both the stability and the geometry of adducts through DFT calculations.

\section{Computational Analysis}

By using the $M 06 / 6-311+G^{*}$ level of theory and the polarizable continuum model (PCM), to account for solvation by THF, molecular structures of the experimentally characterized adducts were reproduced with a satisfying accuracy (see Table S2 in the Supporting Information). The relative stabilities of the adducts were computed and the results (Table 2) were found to be in agreement with experimental data. Indeed, the formation of different $\mathrm{ZO}_{2}$-guanidine adducts was found exergonic (except for $\mathrm{TBD}-\mathrm{CO}_{2}$, entry 2, Table 2) and $\mathrm{SO}_{2}$ adducts were confirmed to be more stable than their $\mathrm{CO}_{2}$ analogues (e.g. $\Delta G=-5.9 \mathrm{kcal} / \mathrm{mol}$ for TBD-SO $\mathrm{SO}_{2}$ compared with $1.9 \mathrm{kcal} / \mathrm{mol}$ for $\mathrm{TBD}-\mathrm{CO}_{2}$, Table 2, Entries 1-2).

Table 2. Calculated Gibbs free energy difference for the formation of different $\mathrm{ZO}_{2}-$ guanidine adducts $(\mathrm{Z}=\mathrm{C}$ or $\mathrm{S})$.

\begin{tabular}{clc}
\hline Entry & Overall reactions & $\Delta G^{[a]}$ \\
\hline 1 & $\mathrm{TBD}+\mathrm{SO}_{2}=\mathrm{TBD}-\mathrm{SO}_{2}$ & -5.9 \\
2 & $\mathrm{TBD}+\mathrm{CO}_{2}=\mathrm{TBD}-\mathrm{CO}_{2}$ & 1.9 \\
3 & $\mathrm{TBD}-\mathrm{SiMe}_{2}{ }^{+}+\mathrm{SO}_{2}=\mathrm{TBD}-\mathrm{SiMe}_{2}-\mathrm{SO}_{2}{ }^{+}$ & -6.0 \\
4 & $\mathrm{TBD}-\mathrm{SiMe}_{2}{ }^{+}+\mathrm{CO}_{2}=\mathrm{TBD}-\mathrm{SiMe}_{2}-\mathrm{CO}_{2}{ }^{+}$ & -0.5 \\
5 & $\mathrm{TBD}-\mathrm{BC} \mathrm{y}_{2}+\mathrm{SO}_{2}=\mathrm{TBD}-\mathrm{BC} \mathrm{y}_{2}-\mathrm{SO}_{2}$ & -6.1 \\
6 & $\mathrm{TBD}-\mathrm{BC} \mathrm{y}_{2}+\mathrm{CO}_{2}=\mathrm{TBD}-\mathrm{BC} \mathrm{y}_{2}-\mathrm{CO}_{2}$ & -3.2 \\
7 & $\mathrm{TBD}-\mathrm{BBN}+\mathrm{SO}_{2}=\mathrm{TBD}-\mathrm{BBN}-\mathrm{SO}_{2}$ & -5.8 \\
8 & $\mathrm{TBD}-\mathrm{BBN}+\mathrm{CO}_{2}=\mathrm{TBD}-\mathrm{BBN}-\mathrm{CO}_{2}$ & -4.8 \\
\hline
\end{tabular}

[a] Calculated relative stability of the adducts expressed as the difference of the Gibbs free energy of the product compared with the starting materials (in $\mathrm{kcal} / \mathrm{mol}$ ).

As depicted in Table 3, consideration of competition reactions reveals a favorable substitution of $\mathrm{CO}_{2}$ by $\mathrm{SO}_{2}$ (average $\Delta G=4.3 \mathrm{kcal} / \mathrm{mol}$ for TBD-E with $\mathrm{E}=\mathrm{H}, \mathrm{SiMe}_{2}{ }^{+}, \mathrm{BBN}$ and $\mathrm{BC}_{2}$, entries 1-4, Table 3). Replacement of a given FLP by one with enhanced Lewis acidic character has also proved to be slightly exergonic (entries 5 and 6, Table 3).

Table 3. Calculated Gibbs free energy difference for competition reactions

\begin{tabular}{clc}
\hline Entry & Overall reactions & $\Delta G^{[\mathrm{a}]}$ \\
\hline 1 & $\mathrm{TBD}-\mathrm{CO}_{2}+\mathrm{SO}_{2}=\mathrm{TBD}-\mathrm{SO}_{2}+\mathrm{CO}_{2}$ & -7.8 \\
2 & $\mathrm{TBD}-\mathrm{SiMe}_{2}-\mathrm{CO}_{2}{ }^{+}+\mathrm{SO}_{2}=\mathrm{TBD}-\mathrm{SiMe}_{2}-\mathrm{SO}_{2}{ }^{+}+\mathrm{CO}_{2}$ & -5.5 \\
3 & $\mathrm{TBD}-\mathrm{BBN}-\mathrm{CO}_{2}+\mathrm{SO}_{2}=\mathrm{TBD}-\mathrm{BBN}-\mathrm{SO}_{2}+\mathrm{CO}_{2}$ & -1.0 \\
4 & $\mathrm{TBD}-\mathrm{BC} \mathrm{y}_{2}-\mathrm{CO}_{2}+\mathrm{SO}_{2}=\mathrm{TBD}-\mathrm{BC} \mathrm{y}_{2}-\mathrm{SO}_{2}+\mathrm{CO}_{2}$ & -2.9 \\
5 & $\mathrm{TBD}-\mathrm{SO}_{2}+\mathrm{TBD}-\mathrm{SiMe}_{2}{ }^{+}=\mathrm{TBD}-\mathrm{SiMe}_{2}-\mathrm{SO}_{2}+\mathrm{TBD}$ & -0.0 \\
6 & $\mathrm{TBD}-\mathrm{SO}_{2}+\mathrm{TBD}-\mathrm{BC} \mathrm{y}_{2}=\mathrm{TBD}-\mathrm{BC} \mathrm{y}_{2}-\mathrm{SO}_{2}+\mathrm{TBD}$ & -0.1 \\
\hline
\end{tabular}

[a] Calculated relative stability of the adducts expressed as the difference of the Gibbs free energy of the product compared with the starting materials (in $\mathrm{kcal} / \mathrm{mol}$ ).

We were interested in understanding the observed difference of thermodynamic stability between the $\mathrm{CO}_{2}$ and the $\mathrm{SO}_{2}$ adducts. The energy associated with the formation of the desired adducts TBD-E- $\mathrm{ZO}_{2}$ (with $\mathrm{E}=\mathrm{H}, \mathrm{SiMe}_{2}{ }^{+}, \mathrm{BBN}$ or $\mathrm{BC} \mathrm{y}_{2}$ and $Z=\mathrm{C}$ or $\mathrm{S}$ ) can be divided into two contributions. As depicted in the thermodynamic cycle in Scheme 7, a first contribution can be defined as the energy required to bend the guanidine and the 
small gaseous molecule into the spatial conformation of the final adduct ( $\left.\Delta E_{\text {deformation }}\right)$, and a second one as the energy of the

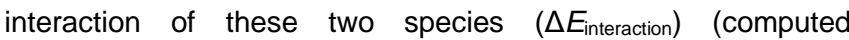
monomeric structures have been used for both borylated TBD $\mathbf{6}_{\mathrm{BR} 2}$ (with $\mathrm{BR}_{2}=\mathrm{BCy}_{2}$ or $\mathrm{BBN}$ ) which have experimentally proven to form dimers). An estimate of the two energetic contributions has been computed using single-point calculations of the two species involved in the adducts and the results are discussed thereafter.

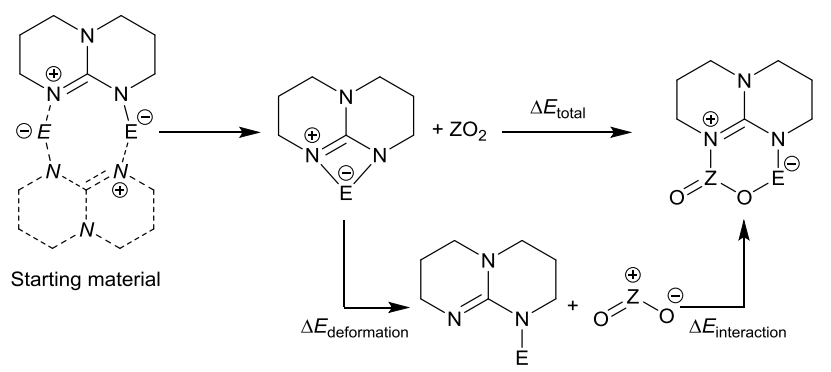

Scheme 7. Thermodynamic cycle for the reaction between guanidine and $\mathrm{ZO}_{2}$ (with $\mathrm{E}=\mathrm{H}, \mathrm{SiMe}_{2}{ }^{+}, \mathrm{BBN}$ or $\mathrm{BCy}_{2}$ and $\mathrm{Z}=\mathrm{C}$ or $\mathrm{S}$ ).

It is notable that the energy cost associated with the deformation of the small molecule increases with the Lewis acidity of the FLP. For instance, $\Delta E_{\text {deformation }}=14.7 \mathrm{kcal} / \mathrm{mol}$ for TBD$\mathrm{SiMe}_{2}-\mathrm{SO}_{2}$ (entry 3) vs $7.0 \mathrm{kcal} / \mathrm{mol}$ for the boryl analogue TBD$\mathrm{BCy}_{2}-\mathrm{SO}_{2}$ (entry 5, Table 4). This trend remains unchanged with the nature of the small molecule $(\Delta E=74.6 \mathrm{kcal} / \mathrm{mol}$ for TBD$\mathrm{SiMe}_{2}-\mathrm{CO}_{2}$, entry 4 , compared with $65.5 \mathrm{kcal} / \mathrm{mol}$ for TBD-BCy ${ }_{2}-$ $\mathrm{CO}_{2}$, entry 6 , Table 4). Additionally, the analysis of the deformation energy of the small molecule in the formation of adducts reveals that values for $\mathrm{CO}_{2}$ adducts are about $50 \mathrm{kcal} / \mathrm{mol}$ higher than those for $\mathrm{SO}_{2}$ (e.g. $\Delta E=65.54 \mathrm{kcal} / \mathrm{mol}$ for TBD$\mathrm{BCy}_{2}-\mathrm{CO}_{2}$, entry 6 , against $7.03 \mathrm{kcal} / \mathrm{mol}$ for $\mathrm{TBD}-\mathrm{BCy}_{2}-\mathrm{SO}_{2}$, entry 5, Table 4). This tendency is consistent with the bent structure of the free $\mathrm{SO}_{2}$ molecule $\left(117.1^{\circ}\right)$ compared with the linear nature of $\mathrm{CO}_{2}$.

Table 4. Calculated deformation energy of the starting materials for the formation of different $\mathrm{ZO}_{2}$-guanidine adducts $(\mathrm{Z}=\mathrm{C}$ or $\mathrm{S})$.

\begin{tabular}{|c|c|c|c|}
\hline Entry & Compound & $\Delta E_{Z O 2 \text { deformation }^{[a]}}$ & $\Delta E_{T B D \text { deformation }}^{[\mathrm{a}]}$ \\
\hline 1 & $\mathrm{TBD}-\mathrm{SO}_{2}$ & 1.7 & 3.3 \\
\hline 2 & $\mathrm{TBD}-\mathrm{CO}_{2}$ & 50.5 & 5.5 \\
\hline 3 & $\mathrm{TBD}-\mathrm{SiMe}_{2}-\mathrm{SO}_{2}{ }^{+}$ & 14.7 & 66.3 \\
\hline 4 & $\mathrm{TBD}-\mathrm{SiMe}_{2}-\mathrm{CO}_{2}{ }^{+}$ & 74.6 & 65.0 \\
\hline 5 & $\mathrm{TBD}-\mathrm{BC} \mathrm{y}_{2}-\mathrm{SO}_{2}$ & 7.0 & 40.6 \\
\hline 6 & $\mathrm{TBD}-\mathrm{BC} \mathrm{y}_{2}-\mathrm{CO}_{2}$ & 65.5 & 45.0 \\
\hline 7 & TBD-BBN-SO ${ }_{2}$ & 9.6 & 34.3 \\
\hline 8 & TBD-BBN-CO ${ }_{2}$ & 64.6 & 40.6 \\
\hline
\end{tabular}

[a] Calculated deformation energy of the small molecule expressed as the difference of the energy of the small molecule in the spatial conformation of the adduct compared with the free small molecule $(Z=C$ or $S$, in $\mathrm{kcal} / \mathrm{mol})$. [b] Calculated deformation energy of the guanidine expressed as the difference of the energy of the guanidine in the spatial conformation of the adduct compared with the free guanidine (in $\mathrm{kcal} / \mathrm{mol}$ ).

In order to verify the validity of this assumption, the energy cost associated with the geometrical deformation of the $\mathrm{ZO}_{2}$ molecule was computed as function of the angle $\mathrm{O}-\mathrm{Z}-\mathrm{O}(\mathrm{Z}=\mathrm{C}$ or $S$, see Figure 2). When plotting the deformation energy and considering the bending of the small molecule in the $7_{\mathrm{Bcy} 2}$ and $8_{\mathrm{BCy} 2}$ adducts geometries, it clearly appears that the energetic gap is far more important for $\mathrm{CO}_{2}$ than $\mathrm{SO}_{2}(\Delta E=63.5 \mathrm{kcal} / \mathrm{mol}$ for TBD-BCy ${ }_{2}-\mathrm{CO}_{2}$ vs $2.2 \mathrm{kcal} / \mathrm{mol}$ for TBD-BCy ${ }_{2}-\mathrm{SO}_{2}$, the difference with the values set out in Table 4 is due to disregarding of the asymmetrisation of the two bonds in this model).

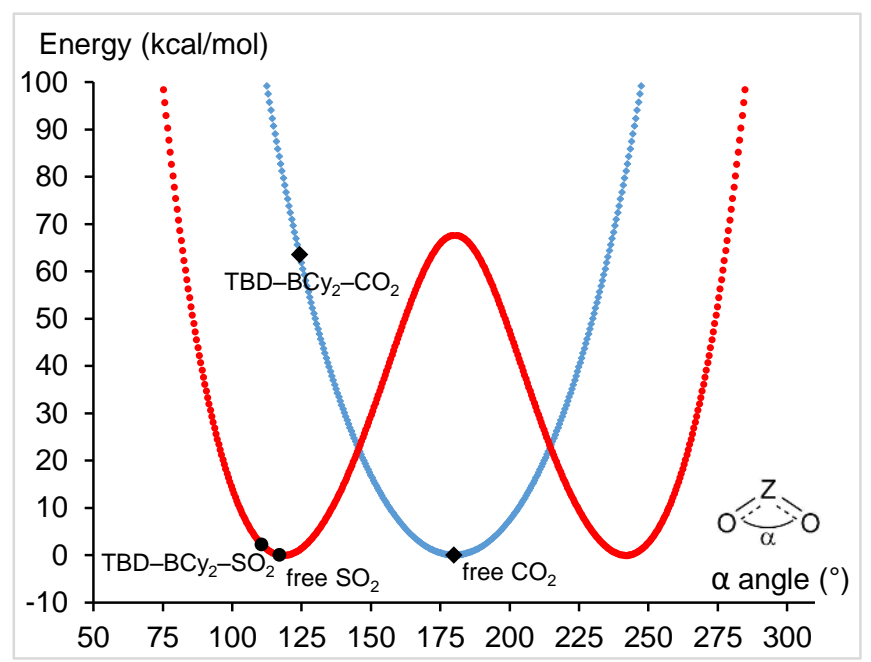

Figure 2. Deformation energies as functions of the $\mathrm{O}-\mathrm{Z}-\mathrm{O}$ angle (in $\mathrm{kcal} / \mathrm{mol}$ and ${ }^{\circ}$, respectively, with $\mathrm{Z}=\mathrm{C}$ or $\left.\mathrm{S}\right)$, using free $\mathrm{ZO}_{2}$ as a reference $(E=0.0$ $\mathrm{kcal} / \mathrm{mol}) .^{[24]}$

Despite the destabilizing strain energy, the formation of the FLP- $\mathrm{ZO}_{2}$ adducts is exergonic (see Table 2). This is owed to the interaction between the guanidine and the small molecule which overcomes the distortion from the equilibrium geometries. Besides, these stabilizing contributions are greater for $\mathrm{CO}_{2}$ adducts $\left(\triangle E=-113.75 \mathrm{kcal} / \mathrm{mol}\right.$ for TBD-BCy ${ }_{2}-\mathrm{CO}_{2}$ against 53.67 $\mathrm{kcal} / \mathrm{mol}$ for TBD-BCy ${ }_{2}-\mathrm{SO}_{2}$, Table 5). This latter fact is also reflected in the calculated Natural Bond Orbital (NBO) charge transfer between the two fragments (approximately twice as important for $\mathrm{CO}_{2}$, see Table 5). It should be noted that the interaction energy is growing with the Lewis acidity of the TBD substituent $\left(\mathrm{SiMe}_{2}{ }^{+}>\mathrm{BBN}>\mathrm{BCy}_{2}>\mathrm{H}\right)$. However, the NBO charge on the small molecule is more important in the absence of a strong Lewis acid, due to the withdrawing character of the latter $\left(q\left(\mathrm{SO}_{2}\right)\right.$ $=-0.36$ for TBD-SO $\mathrm{SO}_{2}$, entry 1 , against -0.20 in average for TBD$\mathrm{E}-\mathrm{SO}_{2}$ with $\mathrm{E}=\mathrm{SiMe}_{2}{ }^{+}, \mathrm{BBN}$ and $\mathrm{BCy} \mathrm{y}_{2}$, entries 3, 5 and 7, Table $5)$. 
Table 5. Calculated interaction energy between distorted starting materials and NBO charge transfer between the FLP and $\mathrm{ZO}_{2}(\mathrm{Z}=\mathrm{C}$ or $\mathrm{S})$.

\begin{tabular}{clcc}
\hline Entry & Compound & $\Delta E_{\text {interaction }}{ }^{[\mathrm{a}]}$ & $q\left(\mathrm{ZO}_{2}\right)^{[\mathrm{b}]}$ \\
\hline 1 & $\mathrm{TBD}-\mathrm{SO}_{2}$ & -22.7 & -0.36 \\
2 & $\mathrm{TBD}-\mathrm{CO}_{2}$ & -64.2 & -0.58 \\
3 & $\mathrm{TBD}-\mathrm{SiMe}_{2}-\mathrm{SO}_{2}{ }^{+}$ & -100.9 & -0.23 \\
4 & $\mathrm{TBD}-\mathrm{SiMe}_{2}-\mathrm{CO}_{2}{ }^{+}$ & -151.9 & -0.45 \\
5 & $\mathrm{TBD}-\mathrm{BC} \mathrm{y}_{2}-\mathrm{SO}_{2}$ & -53.7 & -0.20 \\
6 & $\mathrm{TBD}-\mathrm{BC} \mathrm{y}_{2}-\mathrm{CO}_{2}$ & -113.7 & -0.42 \\
7 & $\mathrm{TBD}-\mathrm{BBN}-\mathrm{SO}_{2}$ & -63.6 & -0.17 \\
8 & $\mathrm{TBD}-\mathrm{BBN}-\mathrm{CO}_{2}$ & -122.2 & -0.40 \\
\hline
\end{tabular}

[a] Calculated interaction energy expressed as the difference of the adduct energy with the energy of starting materials taken in the spatial conformation adopted in the corresponding adduct (in $\mathrm{kcal} / \mathrm{mol}$ ). [b] Sum of the NBO charges on the three atoms of the small molecule $\mathrm{ZO}_{2}(\mathrm{Z}=\mathrm{C}$ or S).

The above-described trend is also mirrored in the calculated energy level of the bonding molecular orbital between the nitrogen $\mathrm{N}^{1}$ of the guanidine and the central atom $\mathrm{Z}$ of the small molecule (more stabilized in the case of $\mathrm{CO}_{2}, E=-0.64$ a.u. for TBD- $\mathrm{CO}_{2}$ against -0.44 for TBD- $\mathrm{SO}_{2}$, see Table 5) and consistent with the calculated Wiberg indices of this same bond (higher for $\mathrm{CO}_{2}$ ). This result could potentially be explained by the greater orbital overlap between the nitrogen and carbon atomic orbitals. Moreover, the repulsion between the lone pair of the guanidine nitrogen atom and the lone pair on the sulfur atom is destabilizing (see Figure 3). Once again, we can observe the importance of the Lewis acid, its strength helps to stabilize the $\mathrm{N}-\mathrm{S}$ bond $(E=-0.44$ a.u. and 0.64 a.u. for $\mathrm{TBD}-\mathrm{SO}_{2}$ and TBD-SiMe ${ }_{2}-\mathrm{SO}_{2}$ respectively).
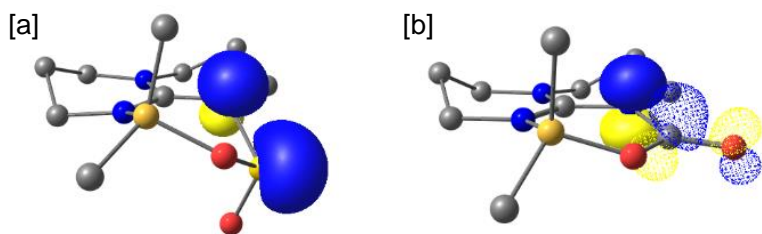

Figure 3. Interactions of the $\mathrm{N}^{1}$ lone pair in TBD- $\mathrm{BC} \mathrm{y}_{2}-\mathrm{ZO}_{2}$ adducts from NBO calculations $(\mathrm{Z}=\mathrm{C}$ or $\mathrm{S}$, hydrogens and cyclohexyl groups are omitted for clarity). Occupied NBOs are drawn as solid surfaces and vacant NBOs as mesh surfaces. [a] Repulsive interaction between the filled $\mathrm{N}^{1}$ and $\mathrm{S}$ lone pairs in $\mathrm{TBD}-\mathrm{BC} \mathrm{y}_{2}-\mathrm{SO}_{2}$; [b] stabilizing interaction between the occupied $\mathrm{N}^{1}$ lone pair and the vacant $\mathrm{C}-\mathrm{O}^{1}$ antibond $\left(\pi^{*}\right)$ in $\mathrm{TBD}-\mathrm{BCy}_{2}-\mathrm{CO}_{2}$

Table 6. Key parameters concerning the $\mathrm{N}^{1} \mathrm{Z}$ bond.

\begin{tabular}{|c|c|c|c|}
\hline Entry & Compound & $\begin{array}{l}\text { Energy of the } N^{1}-Z \\
N^{1} O^{[a]}\end{array}$ & $\mathrm{N}^{1} Z$ Wiberg Index ${ }^{[\mathrm{b}]}$ \\
\hline
\end{tabular}

\begin{tabular}{llll}
\hline 1 & $\mathrm{TBD}_{2} \mathrm{SO}_{2}$ & -0.44 & 0.47 \\
2 & $\mathrm{TBD}-\mathrm{CO}_{2}$ & -0.64 & 0.80 \\
3 & $\mathrm{TBD}-\mathrm{SiMe}_{2}-\mathrm{SO}_{2}{ }^{+}$ & -0.64 & 0.70 \\
4 & $\mathrm{TBD}-\mathrm{SiMe}_{2}-\mathrm{CO}_{2}{ }^{+}$ & -0.77 & 0.97 \\
5 & $\mathrm{TBD}-\mathrm{BC} \mathrm{y}_{2}-\mathrm{SO}_{2}$ & -0.58 & 0.68 \\
6 & $\mathrm{TBD}-\mathrm{BC} \mathrm{y}_{2}-\mathrm{CO}_{2}$ & -0.72 & 0.95 \\
7 & $\mathrm{TBD}-\mathrm{BBN}-\mathrm{SO}_{2}$ & -0.58 & 0.66 \\
8 & $\mathrm{TBD}-\mathrm{BBN}-\mathrm{CO}_{2}$ & -0.71 & 0.95 \\
\hline
\end{tabular}

[a] Calculated energy of the NBO between the guanidine bonding nitrogen and the small molecule central atom (in a.u.). [b] Wiberg matrix elements between the guanidine bonding nitrogen and the small molecule central atom from NBO calculations.

Finally, the elongation of the $\mathrm{Z}-\mathrm{O}^{1}$ bond length is more pronounced for $\mathrm{CO}_{2}$ (in average, $10.97 \%$ elongation for the $\mathrm{C}-\mathrm{O}^{1}$ bond compared with $7.23 \%$ for the $\mathrm{SO}^{1}$, Table 7 ). The double bond character in the free $\mathrm{SO}_{2}$ and $\mathrm{CO}_{2}$ molecules - with Wiberg indices of 1.53 and 1.88 , respectively - is lowered to 1.55 and 1.28 , respectively, in the adducts (Table 7 ). In addition, increasing the Lewis acidity of the $\mathrm{E}$ group $\left(\mathrm{E}=\mathrm{SiMe}_{2}{ }^{+}>\mathrm{BBN}>\mathrm{BCy}_{2}>\mathrm{H}\right)$ results in a greater elongation of the $\mathrm{Z}-\mathrm{O}^{1}$ bonds.

Table 7. Key parameters concerning the $\mathrm{Z}-\mathrm{O}^{1}$ bond deformation.

\begin{tabular}{|c|c|c|c|c|}
\hline Entry & Compound & $\begin{array}{l}\text { ZO' Wiberg } \\
\text { Index }\end{array}$ & $\begin{array}{r}\text { ZO }^{1} \text { Bond } \\
\text { Lenght }^{[b]}\end{array}$ & $\begin{array}{r}\% \text { age of } \\
\text { elongation }{ }^{[c]}\end{array}$ \\
\hline 1 & $\mathrm{TBD}-\mathrm{SO}_{2}$ & 1.25 & 1.49 & 2.77 \\
\hline 2 & $\mathrm{TBD}-\mathrm{CO}_{2}$ & 1.45 & 1.24 & 7.33 \\
\hline 3 & $\mathrm{TBD}_{-} \mathrm{SiMe}_{2}-\mathrm{SO}_{2}{ }^{+}$ & 0.80 & 1.61 & 11.16 \\
\hline 4 & $\mathrm{TBD}_{-} \mathrm{SiMe}_{2}-\mathrm{CO}_{2}{ }^{+}$ & 1.05 & 1.32 & 14.11 \\
\hline 5 & $\mathrm{TBD}-\mathrm{BC} \mathrm{y}_{2}-\mathrm{SO}_{2}$ & 0.94 & 1.55 & 7.19 \\
\hline 6 & $\mathrm{TBD}-\mathrm{BC} \mathrm{y}_{2}-\mathrm{CO}_{2}$ & 1.17 & 1.28 & 10.96 \\
\hline 7 & TBD-BBN-SO ${ }_{2}$ & 0.94 & 1.56 & 7.83 \\
\hline 8 & $\mathrm{TBD}-\mathrm{BBN}-\mathrm{CO}_{2}$ & 1.16 & 1.29 & 11.46 \\
\hline
\end{tabular}

[a] Wiberg matrix elements between the central small molecule atom $Z$ and the bonding oxygen from NBO calculations. [b] Calculated PCM (solvent = THF) bond length between the central small molecule atom and the bonding oxygen (in $\AA$ ). [c] Percentage of elongation of the $\mathrm{Z}-\mathrm{O}^{1}$ bond length between the adduct and the free small molecule.

\section{Conclusions}

In conclusion, we have shown that FLP scaffolds associating functionalized guanidines (TBD) with boryl- or silylium-based Lewis acids (E) could efficiently react with $\mathrm{SO}_{2}$ to 
yield a new family of stable and fully characterized adducts TBD$\mathrm{E}-\mathrm{SO}_{2}\left(\mathrm{E}=\mathrm{SiR}_{2}{ }^{+}\right.$or $\left.\mathrm{BR}_{2}\right)$. The structural analysis of the adducts demonstrates that they are similar to these involving $\mathrm{CO}_{2}$. The greater thermodynamic stability of the $\mathrm{SO}_{2}$ adducts compared to the $\mathrm{CO}_{2}$ analogues was evidenced experimentally and discussed from a theoretical standpoint. Two distinct energy contributions govern the formation of these adducts. On one hand, the endergonic deformation of the $\mathrm{ZO}_{2}$ molecule upon the formation of the TBD-E- $-\mathrm{ZO}_{2}$ adduct is much higher for $\mathrm{CO}_{2}$ than for $\mathrm{SO}_{2}$, mirroring the necessity of bending the linear $\mathrm{CO}_{2}$ molecule. On the other hand, the interaction energy resulting from the coordination of the $\mathrm{ZO}_{2}$ molecule inside the FLP pocket is stabilizing, and greater for $\mathrm{CO}_{2}$ than for $\mathrm{SO}_{2}$. This also attests to a more pronounced charge transfer from TBD to $\mathrm{CO}_{2}$. Moreover, it was proven that a higher acidity of the Lewis acid $(\mathrm{E})$, gives rise to a higher interaction between the TBD-E moiety and the $\mathrm{ZO}_{2}$ molecule.

\section{Experimental Section}

\section{General considerations}

All reactions were carried out under argon with the rigorous exclusion of air and water (<5 ppm oxygen or water) using standard Schlenk-vessel and vacuum line techniques or a glovebox (recirculating mBraun LabMaster DP). Glassware was dried overnight at $60{ }^{\circ} \mathrm{C}$ before use. Solvents were thoroughly dried by standard methods and distilled immediately before use. ${ }^{1} \mathrm{H},{ }^{13} \mathrm{C},{ }^{11} \mathrm{~B}$ and ${ }^{29} \mathrm{Si}$ NMR spectra were obtained by using a Bruker DPX $200 \mathrm{MHz}$ or a Bruker Avance Neo $400 \mathrm{MHz}$ spectrometer. Chemical shifts for ${ }^{1} \mathrm{H}$ and ${ }^{13} \mathrm{C}\left\{{ }^{1} \mathrm{H}\right\}$ NMR spectra were referenced to solvent impurities. Chemical shifts for ${ }^{11} \mathrm{~B} \mathrm{NMR}{ }^{29} \mathrm{Si}$ spectra were referenced by using $\mathrm{Et}_{2} \mathrm{O} \cdot \mathrm{BF}_{3}$ and $\mathrm{Me}_{4} \mathrm{Si}$ as external standards respectively. Coupling constants $\mathrm{J}$ are given in $\mathrm{Hz}$. Unless otherwise noted, reagents were purchased from commercial suppliers and dried over molecular sieves $(4 \AA)$ prior to use. Solvents (THF, ds-THF, toluene, pentane, benzene and CD) were thoroughly dried by standard methods, distilled immediately before use and stored over molecular sieves (4 $\AA$ ). The molecular sieves ( $4 \AA$; Aldrich) were dried under a dynamic vacuum at $250{ }^{\circ} \mathrm{C}$ for $48 \mathrm{~h}$ prior to use. $\mathrm{KH}$ and $\mathrm{NaH}$ in oil were purchased from Aldrich. They were filtered, washed with toluene and kept under argon. Carbon dioxide was purchased from Messer in a 5.5 purity gas bottle. $\mathrm{SO}_{2}$ was released by thermal decomposition of $\mathrm{K}_{2} \mathrm{~S}_{2} \mathrm{O}_{5}$ at temperatures > $190^{\circ} \mathrm{C}$. Reaction is rapid at $\mathrm{T} \sim 500-600^{\circ} \mathrm{C}$ with a heat gun. TBD was obtained from Aldrich and recrystallized in toluene before use. $[\mathrm{TBD}][\mathrm{Na}],{ }^{[25]}\left[\mathrm{TBD}-\mathrm{SiMe}_{2}\right][\mathrm{Cl}]^{[19]},[\mathrm{TBD}-\mathrm{BBN}]_{2}{ }^{[18]}$ and $\mathrm{HBCy}_{2}{ }^{[26]}$ were synthesized according to literature procedures.

\section{Computational details}

The M06 functional was employed to optimize the equilibrium molecular structure of the model compounds. This functional was specifically developed to describe organic systems with nonbonding interactions. The $6-311+G^{*}$ sets were used for all atoms. All the geometries were fully optimized without any symmetry or geometry constrains. Harmonic vibrational analyses were performed to confirm and characterize the structures as minima. Free energies were calculated within the harmonic approximation for vibrational frequencies. The effect of the THF solvent on the energy demand was evaluated with the polarizable-continuum model
(PCM). All the calculations were carried out by using the Gaussian09 suite of codes.

\section{Synthesis}

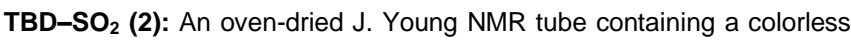
solution of TBD (10 mg, $0.072 \mathrm{mmol}, 1$ equiv.) in $400 \mu \mathrm{L}$ of $d_{8}$-THF under argon was degassed by freezing the solution in liquid nitrogen and evacuation under vacuum. This tube was connected to a fitted small vacuum line involving a flask containing $\mathrm{K}_{2} \mathrm{~S}_{2} \mathrm{O}_{5}(68.9 \mathrm{mg}, 0.288 \mathrm{mmol}, 4$ equiv.) (see picture in $\mathrm{SI}$ ). After three evacuation/argon cycles, under static vacuum, $\mathrm{K}_{2} \mathrm{~S}_{2} \mathrm{O}_{5}$ was heated at $600{ }^{\circ} \mathrm{C}$ with a heat gun. Degradation released pale yellow $\mathrm{SO}_{2}$ vapors which were condensed in the NMR tube cooled under liquid nitrogen ( 2 minutes). The valve of the NMR tube was then closed and the mixture warmed to room temperature. Complex $\mathbf{2}$ was formed immediately as checked by ${ }^{1} \mathrm{H}$ and ${ }^{13} \mathrm{C}\left\{{ }^{1} \mathrm{H}\right\}$ NMR spectroscopy in $d_{8}$-THF. Colorless crystals suitable for $\mathrm{X}$-ray diffraction studies were grown by slow diffusion of pentane into a THF solution of TBD under 2 equiv. of $\mathrm{SO}_{2 .}{ }^{1} \mathrm{H}$ NMR $\left(d_{8}\right.$-THF, $298 \mathrm{~K}$ ): $\delta=7.72$ (br s, 1H, TBD-H), 3.26 (pseudo$\mathrm{t}, 4 \mathrm{H}, \mathrm{CH}_{2}$ TBD), 3.21 (pseudo-t, 4H, $\mathrm{CH}_{2} \mathrm{TBD}$ ), 1.87 (m, 4H, $\mathrm{CH}_{2} \mathrm{TBD}$ ). ${ }^{13} \mathrm{C}$ NMR $\left(d_{8}-\mathrm{THF}, 298 \mathrm{~K}\right): \delta=152.64\left(\mathrm{NCN}_{2}\right), 47.94\left(\mathrm{CH}_{2} \mathrm{TBD}\right), 38.40$ $\left(\mathrm{CH}_{2} \mathrm{TBD}\right), 22.37\left(\mathrm{CH}_{2} \mathrm{TBD}\right)$.

TBD-SiMe $2-\mathrm{SO}_{2}(5[\mathrm{Cl}])$ : An oven-dried J. Young NMR tube containing a colorless solution of [TBD-SiMe 2$][\mathrm{Cl}](3[\mathrm{Cl}])(10 \mathrm{mg}, 0.043 \mathrm{mmol}, 1$ equiv.) in $400 \mu \mathrm{L}$ of $\mathrm{CD}_{2} \mathrm{Cl}_{2}$ under argon was degassed by freezing the solution in liquid nitrogen and evacuation under vacuum. This tube was connected to a fitted small vacuum line involving a flask containing $\mathrm{K}_{2} \mathrm{~S}_{2} \mathrm{O}_{5}(38.4 \mathrm{mg}$, $0.172 \mathrm{mmol}, 4$ equiv.) (see picture in $\mathrm{SI}$ ). After three evacuation/argon cycles, under static vacuum, $\mathrm{K}_{2} \mathrm{~S}_{2} \mathrm{O}_{5}$ was heated at $600^{\circ} \mathrm{C}$ with a heat gun. Degradation released pale yellow $\mathrm{SO}_{2}$ vapors which were condensed in the NMR tube cooled under liquid nitrogen ( 2 minutes). The valve of the NMR tube was then closed and the mixture warmed to room temperature. Complex $5[\mathrm{Cl}]$ was formed immediately as checked by ${ }^{1} \mathrm{H},{ }^{13} \mathrm{C}\left\{{ }^{1} \mathrm{H}\right\}$ and ${ }^{29} \mathrm{Si} N M R$ spectroscopy in $\mathrm{CD}_{2} \mathrm{Cl}_{2}$. ${ }^{1} \mathrm{H}$ NMR $\left(\mathrm{CD}_{2} \mathrm{Cl}_{2}, 298 \mathrm{~K}\right): \delta=3.63(\mathrm{~m}$, 8H, $\mathrm{CH}_{2} \mathrm{TBD}$ ), 2.16 (pseudo-quint, 4H, $\mathrm{CH}_{2} \mathrm{TBD}$ ), 0.70 (s, $6 \mathrm{H}, \mathrm{Si}\left(\mathrm{CH}_{3}\right)_{2}$ ). ${ }^{13} \mathrm{C}$ NMR $\left(\mathrm{CD}_{2} \mathrm{Cl}_{2}, 298 \mathrm{~K}\right): \delta=152.50\left(\mathrm{NCN}_{2}\right), 49.15\left(\mathrm{CH}_{2} \mathrm{TBD}\right), 41.52$ $\left(\mathrm{CH}_{2} \mathrm{TBD}\right), 21.05\left(\mathrm{CH}_{2} \mathrm{TBD}\right),-0.59\left(\mathrm{Si}\left(\mathrm{CH}_{3}\right)_{2}\right) .{ }^{29} \mathrm{Si} \mathrm{NMR}\left(\mathrm{CD}_{2} \mathrm{Cl}_{2}, 298 \mathrm{~K}\right)$ : $\delta=11.69$ (s).

[TBD-BCy $\left.]_{2}\right]_{2}\left(6_{\mathrm{BCy}}\right)$ : An oven-dried J. Young NMR tube was charged with TBD (10 mg, $0.072 \mathrm{mmol}, 1$ equiv.), HBCy2 (12.8 mg, $0.072 \mathrm{mmol}, 1$ equiv.), and $400 \mu \mathrm{L}$ of $d_{8}$-THF under argon. The tube was sealed, and the reaction mixture was stirred for $4 \mathrm{~h}$ at $80^{\circ} \mathrm{C}$. Complex $6_{\mathrm{BCy} 2}$ was identified by ${ }^{1} \mathrm{H},{ }^{13} \mathrm{C}\left\{{ }^{1} \mathrm{H}\right\}$ and ${ }^{11} \mathrm{~B}$ NMR spectroscopy in $d_{8}$-THF. ${ }^{1} \mathrm{H}$ NMR ( $d_{8}$-THF, $298 \mathrm{~K}$ ): $\delta=3.11$ (t, J = 5.8 Hz, 8H, CH $2 \mathrm{TBD}$ ), 3.01 (pseudo-t, $8 \mathrm{H}, \mathrm{CH}_{2}$ TBD), 1.99 (pseudo-quint, 8H, $\mathrm{CH}_{2}$ TBD), 1.66 (m, 12H, $\mathrm{CH}_{2} \mathrm{Cy}$ ), 1.60 (m, $\left.4 \mathrm{H}, \mathrm{CH}_{2} \mathrm{Cy}\right), 1.56$ (m, 4H, $\left.\mathrm{CH}_{2} \mathrm{Cy}\right), 1.18$ (m, 12H, CH $\left.\mathrm{CH}_{2} \mathrm{Cy}\right), 0.92(\mathrm{~m}, 8 \mathrm{H}$, $\mathrm{CH}_{2} \mathrm{Cy}$ ), 0.54 (tt, J = 12.1, 3.0 Hz, 4H, CH Cy). ${ }^{13} \mathrm{C}$ NMR (ds-THF, $\left.298 \mathrm{~K}\right)$ : $\delta=155.94\left(\mathrm{NCN}_{2}\right), 45.50\left(\mathrm{CH}_{2} \mathrm{TBD}\right), 40.56\left(\mathrm{CH}_{2} \mathrm{TBD}\right), 30.50\left(\mathrm{CH}_{2} \mathrm{Cy}\right)$, 29.51 ( $\left.\mathrm{CH}_{2} \mathrm{Cy}\right), 28.63\left(\mathrm{CH}_{2} \mathrm{TBD}\right), 27.57$ ( $\left.\mathrm{CH} \mathrm{Cy}\right), 24.54\left(\mathrm{CH}_{2} \mathrm{Cy}\right) .{ }^{11} \mathrm{~B}$ NMR ( $\left.d_{8}-\mathrm{THF}, 298 \mathrm{~K}\right): \delta=11.77$ (br s).

TBD-BCy ${ }_{2}-\mathrm{CO}_{2}\left(7_{\mathrm{BCy} 2}\right)$ : An oven-dried J. Young NMR tube was charged with $6_{\mathrm{BCy} 2}\left(22.7 \mathrm{mg}, 0.036 \mathrm{mmol}, 1\right.$ equiv.), and $400 \mu \mathrm{L}$ of $d_{8}$-THF under argon. The reaction mixture was exposed to a $\mathrm{CO}_{2}$ atmosphere (1 bar). A white precipitate was formed and complex $7_{\mathrm{BCy} 2}$ identified by ${ }^{1} \mathrm{H},{ }^{13} \mathrm{C}\left\{{ }^{1} \mathrm{H}\right\}$ and ${ }^{11} \mathrm{~B}$ NMR spectroscopy in $d_{8}$-THF. ${ }^{1} \mathrm{H}$ NMR $\left(d_{8}\right.$-THF, $\left.298 \mathrm{~K}\right): \delta=3.71$ (pseudo-t, 2H, CH $\mathrm{CH}_{2}$ TBD), 3.39 (pseudo-t, 2H, $\mathrm{CH}_{2}$ TBD), 3.33 (pseudo-t, 2H, $\mathrm{CH}_{2}$ TBD), 3.24 (pseudo-t, 2H, $\mathrm{CH}_{2} \mathrm{TBD}$ ), 1.96 (m, 4H, $\mathrm{CH}_{2}$ TBD), 1.69 (m, 6H, CH $\mathrm{CH}_{2} \mathrm{Cy}$ ), 1.59 (m, 2H, $\left.\mathrm{CH}_{2} \mathrm{Cy}\right), 1.51$ (m, 2H, $\left.\mathrm{CH}_{2} \mathrm{Cy}\right), 1.21$ (m, 6H, $\left.\mathrm{CH}_{2} \mathrm{Cy}\right), 0.50$ (t, J = $\left.12.1 \mathrm{~Hz}, 2 \mathrm{H}, \mathrm{CH} \mathrm{Cy}\right) .{ }^{13} \mathrm{C} \mathrm{NMR}\left(d_{8}-\mathrm{THF}, 298 \mathrm{~K}\right): \delta=$ 150.40 (OCO), 150.12 (NCN2), 49.12 ( $\left.\mathrm{CH}_{2} \mathrm{TBD}\right), 48.83$ ( $\left.\mathrm{CH}_{2} \mathrm{TBD}\right), 41.77$ $\left(\mathrm{CH}_{2} \mathrm{TBD}\right), 41.57$ ( $\mathrm{CH}_{2}$ TBD), 30.22, 29.74, 29.57, 29.29, $28.85\left(\mathrm{CH}_{2} \mathrm{Cy}\right)$ 
27.56 (CH Cy), 21.89 ( $\mathrm{CH}_{2}$ TBD), $21.43\left(\mathrm{CH}_{2} \mathrm{TBD}\right) .{ }^{11} \mathrm{~B}$ NMR $\left(d_{8}-\mathrm{THF}, 298\right.$ $\mathrm{K}): \delta=5.05(\mathrm{br} \mathrm{s})$

TBD-BCy ${ }_{2}-\mathrm{SO}_{2}\left(8_{\mathrm{BCy}}\right)$ : An oven-dried J. Young NMR tube was charged with $6_{\mathrm{BCy} 2}\left(22.7 \mathrm{mg}, 0.036 \mathrm{mmol}, 1\right.$ equiv.), and $400 \mu \mathrm{L}$ of $d_{8}$-THF under argon was degassed by freezing the solution in liquid nitrogen and evacuation under vacuum. This tube was connected to a fitted small vacuum line involving a flask containing $\mathrm{K}_{2} \mathrm{~S}_{2} \mathrm{O}_{5}(68.9 \mathrm{mg}, 0.288 \mathrm{mmol}, 8$ equiv.) (see picture in $\mathrm{SI}$ ). After three evacuation/argon cycles, under static vacuum, $\mathrm{K}_{2} \mathrm{~S}_{2} \mathrm{O}_{5}$ was heated at $600{ }^{\circ} \mathrm{C}$ with a heat gun. Degradation released pale yellow $\mathrm{SO}_{2}$ vapors which were condensed in the NMR tube cooled under liquid nitrogen ( 2 minutes). The valve of the NMR tube was then closed and the mixture warmed to room temperature. Complex $\mathbf{8}_{\mathrm{BCy}}$ was formed immediately as checked by ${ }^{1} \mathrm{H},{ }^{13} \mathrm{C}\left\{{ }^{1} \mathrm{H}\right\}$ and ${ }^{11} \mathrm{~B}$ NMR spectroscopy in $d_{8}$-THF. ${ }^{1} \mathrm{H}$ NMR $\left(d_{8}\right.$-THF, $\left.298 \mathrm{~K}\right): \delta=3.51\left(\mathrm{~m}, 1 \mathrm{H}, \mathrm{CH}_{2}\right.$ TBD), 3.25-3.34 (m, 6H, CH 2 TBD), 3.19 (m, 2H, $\mathrm{CH}_{2}$ TBD), $1.91(\mathrm{~m}, 4 \mathrm{H}$, $\mathrm{CH}_{2}$ TBD), 1.73 (m, 6H, CH $\left.2 \mathrm{Cy}\right), 0.87-1.29\left(\mathrm{~m}, 10 \mathrm{H}, \mathrm{CH}_{2} \mathrm{Cy}\right), 0.55(\mathrm{~m}, 2 \mathrm{H}$, $\mathrm{CH}$ Cy). ${ }^{13} \mathrm{C}$ NMR $\left(d_{8}-\mathrm{THF}, 298 \mathrm{~K}\right): \delta=151.71\left(\mathrm{NCN}_{2}\right), 49.01\left(\mathrm{CH}_{2} \mathrm{TBD}\right)$ 48.77 ( $\left.\mathrm{CH}_{2} \mathrm{TBD}\right), 42.14$ ( $\left.\mathrm{CH}_{2} \mathrm{TBD}\right), 39.65\left(\mathrm{CH}_{2} \mathrm{TBD}\right), 30.49,29.87,29.80$, 29.69, 28.61 ( $\left.\mathrm{CH}_{2} \mathrm{Cy}\right), 27.59$ (CH Cy), 22.50 ( $\left.\mathrm{CH}_{2} \mathrm{TBD}\right), 21.94\left(\mathrm{CH}_{2} \mathrm{TBD}\right)$. ${ }^{11} \mathrm{~B}$ NMR $\left(d_{8}\right.$-THF, $\left.298 \mathrm{~K}\right): \delta=7.46(\mathrm{br} \mathrm{s})$

TBD-BBN-SO ${ }_{2}\left(8_{\mathrm{BBN}}\right)$ : An oven-dried J. Young NMR tube was charged with [TBD][Na] (10 mg, $0.062 \mathrm{mmol}, 1$ equiv.), and $400 \mu \mathrm{L}$ of $d_{8}$-THF under argon was degassed by freezing the solution in liquid nitrogen and evacuation under vacuum. This tube was connected to a fitted small vacuum line involving a flask containing $\mathrm{K}_{2} \mathrm{~S}_{2} \mathrm{O}_{5}$ (55.2 mg, $0.248 \mathrm{mmol}, 4$ equiv.) (see picture in $\mathrm{SI}$ ). After three evacuation/argon cycles, under static vacuum, $\mathrm{K}_{2} \mathrm{~S}_{2} \mathrm{O}_{5}$ was heated at $600{ }^{\circ} \mathrm{C}$ with a heat gun. Degradation released pale yellow $\mathrm{SO}_{2}$ vapors which were condensed in the NMR tube cooled under liquid nitrogen ( 2 minutes). Under argon, B-lodo-9-BBN (62 $\mu \mathrm{L}, 1 \mathrm{M}$ solution in hexanes, $0.062 \mathrm{mmol}, 1$ equiv.) was added and the reaction mixture was stirred for $1 \mathrm{~h}$ at room temperature. Complex $8_{\mathrm{BBN}}$ was obtained with a ca $80 \%$ yield and identified by ${ }^{1} \mathrm{H},{ }^{13} \mathrm{C}\left\{{ }^{1} \mathrm{H}\right\}$ and ${ }^{11} \mathrm{~B}$ NMR spectroscopy in $d_{8}$-THF. ${ }^{1} \mathrm{H}$ NMR $\left(d_{8}\right.$-THF, $298 \mathrm{~K}$ ): $\delta=3.48$ (pseudot, 4H, $\mathrm{CH}_{2}$ TBD), 3.33 (pseudo-t, 4H, $\mathrm{CH}_{2} \mathrm{TBD}$ ), 2.18-2.19 (m, 2H, $\mathrm{CH}_{2}$ BBN), 1.76-2.04 (m, 8H, $\mathrm{CH}_{2}$ TBD and $\left.\mathrm{CH}_{2} \mathrm{BBN}\right), 1.68\left(\mathrm{~m}, 2 \mathrm{H}, \mathrm{CH}_{2} \mathrm{BBN}\right)$, 1.42-1.47 (m, 4H, CH 2 BBN), 0.90 (br s, $2 \mathrm{H}, \mathrm{CH} B B N) .{ }^{13} \mathrm{C}$ NMR ( $d_{8}$-THF, $298 \mathrm{~K}): \delta=152.10\left(\mathrm{NCN}_{2}\right), 48.88\left(\mathrm{CH}_{2} \mathrm{TBD}\right), 48.44\left(\mathrm{CH}_{2} \mathrm{TBD}\right), 42.79$ $\left(\mathrm{CH}_{2} \mathrm{TBD}\right), 40.63$ ( $\left.\mathrm{CH}_{2} \mathrm{TBD}\right), 33.07$ (BBN), 32.90 (BBN), $23.05\left(\mathrm{CH}_{2} \mathrm{TBD}\right)$ $22.86\left(\mathrm{CH}_{2} \mathrm{TBD}\right), 21.90(\mathrm{BBN}), 21.41(\mathrm{BBN}), 21.10(\mathrm{BBN}) .{ }^{11} \mathrm{~B}$ NMR $\left(d_{8}\right.$ THF, $298 \mathrm{~K}): \delta=7.89(\mathrm{br} \mathrm{s})$

\section{Acknowledgements}

For financial support of this work, we acknowledge CEA, CNRS, the University Paris-Saclay, CINES, the CHARMMMAT Laboratory of Excellence and the European Research Council (ERC Starting Grant Agreement no. 336467). T.C. thanks the Fondation Louis D. - Institut de France for its formidable support. .

Keywords: $\mathrm{FLP} \cdot \mathrm{SO}_{2}$ activation $\cdot \mathrm{CO}_{2}$ activation $\cdot \mathrm{DFT}$ calculations $\cdot \mathrm{X}$-ray diffraction

[1] D. W. Stephan, G. Erker, Angew. Chem. Int. Ed. 2015, 54, 6400-6441.

[2] a) G. C. Welch, R. S. San Juan, J. D. Masuda, D. W. Stephan, Science 2006, 314, 1124-1126; b) G. C. Welch, D. W. Stephan, J. Am. Chem. Soc. 2007, 129, 1880-1881; c) P. Spies, G. Erker, G. Kehr, K. Bergander, R. Fröhlich, S. Grimme, D. W. Stephan, Chem. Commun. 2007, 0, 5072 5074.
[3] a) J. S. J. McCahill, G. C. Welch, D. W. Stephan, Angew.Chem. 2007 119, 5056-5059; b) X. Zhao, D. W. Stephan, J. Am. Chem. Soc. 2011, 133, 12448-12450; c) X. Zhao, D. W. Stephan, Chem. Sci. 2012 3, 2123-2132; d) T. Voss, C. Chen, G. Kehr, E. Nauha, G. Erker, D. W. Stephan, Chem. Eur. J. 2010, 16, 3005-3008; e) P. K. Dornan, L. E. Longobardi, D. W. Stephan, Synlett 2014, 25, 1521-1524.

[4] a) M. A. Dureen, D. W. Stephan, J. Am. Chem. Soc. 2009, 131, 83968397 ; b) M. A. Dureen, C. C. Brown, D. W. Stephan, Organometallics, 2010, 29, 6594-6607; c) A. Fukazawa, H. Yamada, S. Yamaguchi, Angew.Chem. 2008, 120, 5664-5667; d) S. J. Geier, M. A Dureen, E. Y. Ouyang, D. W. Stephan, Chem. Eur. J. 2010, 16, 988-993.

[5] a) J. Backs, M. Lange, J. Possart, A. Wollschläger, C. Mück-Lichtenfeld, W. Uhl, Angew. Chem. Int. Ed. 2017, 56, 3094-3097; b) A. Stute, L. Heletta, R. Fröhlich, C. G. Daniliuc, G. Kehr, G. Erker, Chem. Commun. 2012, 48, 11739-11741; c) C. M. Mömming, G. Kehr, B. Wibbeling, R Fröhlich, G. Erker, Dalton Trans. 2010, 39, 7556-7564; d) X. Xu, G. Kehr, C. G. Daniliuc, G. Erker, J. Am. Chem. Soc. 2013, 135, 6465-6476 ; e) V. Cadierno, M. Zablocka, B. Donnadieu, A. Igau, J.-P. Majoral, A. Skowronska, Chem. Eur. J. 2000, 6, 345-352; f) J. Schneider, K. M. Krebs, S. Freitag, K. Eichele, H. Schubert, L. Wesemann, Chem. Eur. J. 2016, 22, 9812-9826; g) M. W. P. Bebbington, S. Bontemps, G. Bouhadir, D. Bourissou, Angew. Chem. Int. Ed. 2007, 46, 3333-3336; h) A. Stute G. Kehr, R. Fröhlich, G. Erker, Chem. Commun. 2011, 47, 4288-4290.

[6] a) S. Moebs-Sanchez, G. Bouhadir, N. Saffon, L. Maron, D. Bourissou, Chem. Commun. 2008, 3435; b) Mömming, C. M.; Frömel, S.; Kehr, G. Fröhlich, R.; Grimme, S.; Erker, G. J. Am. Chem. Soc. 2009, 131, 1228012289; c) C. Rosorius, G. Kehr, R. Fröhlich, S. Grimme, G. Erker, Organometallics 2011, 30, 4211.

[7] a) C. M. Mömming, E. Otten, G. Kehr, R. Fröhlich, S. Grimme, D. W. Stephan, G. Erker, Angew. Chem., Int. Ed. 2009, 48, 6643-6646; b) E. Theuergarten, T. Bannenberg, M. D. Walter, D. Holschumacher, M. Freytag, C. G. Daniliuc, P. G. Jones, M. Tamm, Dalton Trans. 2014, 43, 1651-1662; c) D. W. Stephan, J. Am. Chem. Soc. 2015, 137, 1001810032; d) G. Ménard, T. M. Gilbert, J. A. Hatnean, A. Kraft, I. Krossing, D. W. Stephan, Organometallics 2013, 32, 4416-4422; e) A. L. Travis, S. C. Binding, H. Zaher, T. A. Q. Arnold, J.-C. Buffet, D. O'Hare, D. Dalton Trans. 2013, 42, 2431-2437; f) C. Appelt, H. Westenberg, F. Bertini, A. W. Ehlers, J. C. Slootweg, K. Lammertsma, W. Uhl, Angew. Chem. Int. Ed. 2011, 50, 3925-3928; g) G. Ménard, D. W. Stephan, J. Am. Chem. Soc. 2010, 132, 1796-1797; h) F. Bertini, V. Lyaskovskyy, B. J. J. Timmer, F. J. J. de Kanter, M. Lutz, A. W. Ehlers, J. C. Slootweg, K. Lammertsma, J. Am. Chem. Soc. 2012, 134, 201-204; i) M. Reißmann, A. Schafer, S. Jung, T. Müller, Organometallics 2013, 32, 6736-6744; j) B. R. Barnett, C. E. Moore, A. L. Rheingold, J. S. Figueroa, Chem. Commun. 2015, 51, 541-544.

[8] a) M. Aresta, Carbon Dioxide as Chemical Feedstock, Wiley-VCH, Weinheim, 2010; b) A. Tlili, E. Blondiaux, X. Frogneux, T. Cantat, Green Chem. 2015, 17, 157-168; c) Q. Liu, L. Wu, R. Jackstell, M. Beller, Nat. Commun. 2015, 6, 5933-5947.

[9] a) A. E. Ashley, A. L. Thompson, D. O'Hare, Angew. Chem. Int. Ed. 2009, 48, 9839-9843; b) A. Berkefeld, W. E. Piers, M. Parvez, J. Am. Chem. Soc. 2010, 132, 10660-10661; c) K. Takeuchi, D. W. Stephan, Chem. Commun. 2012, 48, 11304-11306; d) G. Ménard, D. W. Stephan, J. Am. Chem. Soc. 2010, 132, 1796-1797; e) M.-A. Courtemanche, M.-A. Légaré, L. Maron, F.-G. Fontaine, J. Am. Chem. Soc. 2013, 135, 9326 9329; f) T. Wang, D. W. Stephan, Chem. Commun. 2014, 50, 7007-7010. 
[10] a) D. H. Ehhalt, Phys. Chem. Chem. Phys. 1999, 1, 5401-5408; b) M. Vahedpour, F. Zolfaghari, Struct. Chem. 2011, 22, 1331-1338.

[11] a) M. M. Rogic, D. Masilamani, J. Am. Chem. Soc. 1977, 99, 5219-5220; b) G. Pelzer, J. Herwig, W. Keim, R. Goddard, Russ. Chem. Bull. 1998 47, 904-913; c) R. V. Hoffman, Org. Synth. 1981, 60, 121-126; d) L. Malet-Sanz, J. Madrzak, S. V. Ley, I. R. Baxendale, Org. Biomol. Chem. 2010, 8, 5324-5332 ; e) P. Vogel, M. Turks, L. Bouchez, D. Markovic, A Varela-Alvarez, J. A. Sordo, Acc. Chem. Res. 2007, 40, 931-942; f) L. M. Wojcinski, II., M. T. Boyer, A. Sen, Inorg. Chim. Acta 1998, 270, 8-11; g A. Deeming, E. Emmett, C. Richards-Taylor, M. Willis, Synthesis 2014 46, 2701-2710.

[12] M. Sajid, A. Klose, B. Birkmann, L. Liang, B. Schirmer, T. Wiegand, H. Eckert, A. J. Lough, R. Frohlich, C. G. Daniliuc, S. Grimme, D. W Stephan, G. Kehr, G. Erker, Chem. Sci. 2013, 4, 213.

[13] J. Möricke, B. Wibbeling, C. G. Daniliuc, G. Kehr, G. Erker, Phil. Trans. R. Soc. A 2017, 375, 20170015.

[14] X. Xu, G. Kehr, C. G. Daniliuc, G. Erker, J. Am. Chem. Soc. 2014, 136, 12431-12443.

[15] B. Waerder, M. Pieper, L. A. Körte, T. A. Kinder, A. Mix, B. Neumann, H.G. Stammler, N. W. Mitzel, Angew. Chem. Int. Ed. 2015, 54, 13416 13419.

[16] a) E. Divers, M. Ogawa, J. Chem. Soc., Trans. 1900, 77, 327-335; b) J. A. Moede, C. Curran, J. Am. Chem. Soc. 1949, 71, 852-858; c) T. Hata S. Kinumaki Nature 1964, 203, 1378-1379; d) D. van der Helm, J. D. Childs, S. D. Christian, Chem. Commun. 1969, 0, 887-888; e) J. E. Douglas, P. A. Kollman, J. Am. Chem. Soc. 1978, 100, 5226-5227; f) M. W. Wong, K. B. Wiberg, J. Am. Chem. Soc. 1992, 114, 7527-7535; g) H. Woolven, C. González-Rodríguez, I. Marco, A. L. Thompson, M. C. Willis, Org. Lett. 2011, 13, 4876-4878.

[17] C. Villiers, J.-P. Dognon, R. Pollet, P. Thuéry, M. Ephritikhine, Angew. Chem. Int. Ed. 2010, 49, 3465-3468.

[18] C. Das Neves Gomes, E. Blondiaux, P. Thuéry, T. Cantat, Chem. Eur. J. 2014, 20, 7098-7106.

[19] N. von Wolff, G. Lefèvre, J.-C. Berthet, P. Thuéry, T. Cantat, ACS Catal. 2016, 6, 4526-4535.

[20] N. von Wolff, C. Villiers, P. Thuéry, G. Lefèvre, M. Ephritikhine, T. Cantat, Eur. J. Org. Chem. 2017, 676-686.

[21] Y. M. Xu, R. P. Schutte, L. G. Hepler, Can. J. Chem. Eng. 1992, 70, 569573.

[22] a) S. Grabowsky, P. Luger, J. Buschmann, T. Schneider, T. Schirmeister, A. N. Sobolev, D. Jayatilaka, Angew. Chem. Int. Ed. 2012, 51, 6776-6779. b) N. Meier, J. Schiewe, H. Matschiner, C.-P. Maschmeier, R. Boese, Phosphorus Sulfur Silicon Relat. Elem. 1994, 91, 179-188; c) J. J. Oh, M. S. LaBarge, J. Matos, J. W. Kampf, K. W. Hillig II, R. L. Kuczkowski J. Am. Chem. Soc. 1991, 113, 4732-4738.

[23] a) M. Gressenbuch, B. Kersting, Dalton Trans. 2009, 5281-5283; b) C. Yue, Z. Lin, L. Chen, F. Jiang, M. Hong, J. Mol. Struct. 2005, 779, 16-22.

[24] A script has been used to retrieve energy values for every point, the script is freely available on GitHub and relies on the cclib library. E. Nicolas, 2018, https://github.com/chemistry-scripts/computations-scripts.

[25] A. A. Mohamed, A. P. Mayer, H. E. Abdou, M. D. Irwin, L. M. Pérez, J. P. Fackler, Inorg. Chem. 2007, 46, 11165-11172.

[26] H. C. Brown, A. K. Mandal, S. U. Kulkarni, J. Org. Chem. 1977, 42, 1392 1398. 